\title{
"GET YOUR FACE OUT OF MINE": CULTURE-ORIENTED DISTANCE IN EFL CONTEXT A Helpful Guide for Turkish EFL Teachers
}

\author{
Servet Çelik
}

\begin{abstract}
This research study aims to find out the experiences of Turkish EFL teachers in the United States regarding the differences between their understanding and use of personal space and that of Americans,' and to discuss how the issue is closely related to foreign language instruction. The study will center around a brand new term that I have coined, 'culture-oriented distance,' as an important part of non-verbal communication. However, in this paper, other forms of non-verbal communication as a general phenomenon will be referred to only briefly. The results will be followed by the implications of culture-oriented distance in foreign language teaching, and specifically Turkish EFL teachers will be presented with many possible ways to incorporate this cultural phenomenon in their language classrooms. Although there will be no attempt to generalize the findings beyond the participants of this study and EFL teaching in Turkey, some results might well be applicable to other contexts.
\end{abstract}

\section{(YABANCI DİL OLARAK İNGILIZCE ÖĞRETIMINNDE KÜLTÜR KAYNAKLI MESAFE: TÜRK ÖĞRETMENLER İÇIN YARARLI BİR REHBER Özet}

Bu çalışma Amerika Birleşik Devletleri’nde özellikle akademik nedenlerle bulunan Türk Ingiliz dil eğitimcilerinin Amerikalılarla 'kişisel mesafe' anlayışı ve kullanımındaki farklılıklar nedeniyle yaşadıkları deneyimleri gün ışığına çıkarmayı ve bu konunun dil eğitimiyle nasıl yakından ilgili olduğunu ortaya koymayı amaçlamaktadır. Araştırma, beden dilinin önemli bir parçası olan 'kültür kaynaklı mesafe' terimi etrafinda odaklanacak olup, beden dilinin diğer örnekleri ayrıntılı olarak tartışılmayacak. Çalışmanın sonuçlarını kültür kaynaklı mesafe konusunun dil eğitimindeki önemi ve kullanımı takip edecek olup Türk Ingiliz dil eğitimcilerinin bu konuyu müfredat ve sınıflarına nasıl aktarabileceklerinin bazı örnekleri sunulacak. Araştırma ve beraberinde getirdikleri çalışmaya katılanlarla ve genel anlamda Türkiye'deki dil eğitimiyle sinırlı tutulacak ve genellemeler yapmada kullanılmayacak olmakla birlikte bazı sonuçlar diğer gruplar için de geçerli olabilir. 


\section{You Speak the Language; Does Your Body, Too?}

August 26, 2001... It is my first time in the United States - the dream land of most people in the world - and I am already late for my connecting flight to Philadelphia. Waiting at the baggage claim took hours. Now I have my luggage and am trying to find my way around the Chicago O'Hare International Airport. I anxiously approach the lady at the information desk of the airline company for help. Although I am nervous and upset, I try to tell her about the situation as I ask if she can put me in the first available flight to my destination. Although I thought I spoke to her in a calm, polite way, she says: 'Get your face out of mine first of all.' I have no idea what is going on and why she reacted the way she did. She acts intimidated and upset even though I thought I was being polite. I would like to feel happy that I have had my very first contact with an American, but instead I feel bad that I have just heard a new expression in English that sounds like it has a negative connotation in the context. I'm speaking her language, but apparently we are not 'communicating.' Something is missing, but what? I can hardly put my worries aside. 'Is my English terrible? Doesn't she like international people?' Then I am relieved that I am being helped, which is the only good thing I can think of. I get my new boarding pass for the next flight to Philadelphia, and start waiting. Observing people is fun. Everyone seems so different than the people I am used to seeing in Turkey; not only are they speaking a different language, but also they look and act differently. I am impressed by the number of people reading books and magazines. These people must love reading. Well, I don't! I can't stop to think that they should quit reading and start exercising though-most are overweight. It is time for my flight and I am delighted to find my seat in the plane.

'I am finally in Philadelphia, where a nation was born. After a few days of exploring this new place, school starts. I also get a part-time job in the computer lab of my school as a lab assistant. A great job for me: just sit and surf the Internet, and help other graduate students with basic computer skills when needed. And of course, continue one of my favorite past-times: observe people! It is interesting to monitor the verbal and non-verbal interactions between people from various countries and cultures. How unwritten rules of personal distance come to play a seemingly important role between these people grabs my attention. Perceiving that especially American students feel uncomfortable and step back as others physically come closer in situations such that they would pick up their print-outs from the printer, in a way answers my question about what has happened with the lady at the airport. As I have spent more time in the United States, I have had the opportunity to make more observations on different occasions, some of which are, but not limited to, classrooms, post offices, restaurants and grocery stores, bus stops, buses, and elevators. As an EFL teacher, I have begun to think about the implications of this culturally oriented phenomenon in language teaching, and how language teachers should incorporate this type of socio-cultural information into their teaching so that their students can not only speak the language, but also 
successfully 'communicate' with the native speakers of the target language, and, that includes how close to stand to people and how to keep one's distance so one will never again be accused of 'getting in someone's face.'

The above personal excerpt is created based on my memories. It is among the foundational experiences that formed my interest in carrying out this study; however, it is not the actual data collected in this research.

In conjunction with the piece above, the next section intends to provide a concise introduction as to what makes personal distance worth researching by declaring that distancing behavior, as part of the non-verbal language use, is an indispensable part of communication in a foreign language.

\section{Why Would I Care?}

While many discussions about foreign language education have focused on teaching methodologies, little emphasis has been given to the different non-verbal communication types in different cultures that should be integrated within these methodologies. However, working successfully with language learners in EFL contexts requires the study of not only the verbal, linguistic features within the language, but also assimilation of the non-linguistic features of that language and cultural rules of its community. Needless to say, human communication is beyond the physical language as we accompany our speech with various movements of the body, the head, and the hands. We use gestures, facial expressions and many vocal noises that cannot be called words. We also communicate subtle meanings by manipulating the space between us and our interlocutors, which has been labeled as 'personal space' (Little 1965) or 'immediacy' (Mehrabian 1967), and the study of this important area in the non-verbal world of language has been called 'proxemics' by Hall 1963.

The aim in this research study is to find out whether Turkish students in the United States come across any difficulties with respect to Americans' understanding and use of interpersonal distance/personal space, and if they do, to find out why they think the distance behaviors vary, and lastly, to suggest ways of integrating this phenomenon into the practices of Turkish EFL teachers to better help their students to be fully competent in the English language.

\section{You Better Watch Your Space, Buddy!}

How individual persons differing in various characteristics use their space zones has accounted for the majority of research to date. Hall 1966, as the pioneer of most studies in this theme, identified four different types of distances Americans tend to maintain:

Intimate distance is from 0 to 1.5 feet $(0-50 \mathrm{~cm})$. What can be done at this close range? Vision is minimal, and we rely on our senses of smell and touch. Making love or comforting someone is an intimate activity, usually restricted to private encounters, which can be performed comfortably at intimate distances. We tend not 
to get this close to people we are not intimate with, and usually try to escape if we do.

Personal distance is from about 1.5 feet to around 4 feet $(50-120 \mathrm{~cm})$. At this distance, touch is minimal (except perhaps when shaking hands), and vision and hearing become important. This is the distance we use to interact with friends. Within this range, normal conversations can take place easily. We might allow strangers into the outer limits, but reserve the inner limits strictly for friends.

Social distance extends from approximately 4 to 12 feet $(120 \mathrm{~cm}-4 \mathrm{~m})$, and includes the space required for more formal social interactions. Hearing and vision are the primary senses involved. The social distance is often utilized in business, for example, in interviewing new applicants for employment or negotiating for a raise.

Public distance includes distances greater than 12 feet $(4 \mathrm{~m})$. Hall suggested that after 25 feet $(8 \mathrm{~m})$, interpersonal interaction is not possible. At this distance there is little detail involved in communication. A public speaker (actor or politician) communicates only one way with an audience.

In discussing Hall's space zones, Little 1965 states that 'they are a series of fluctuating concentric globes of space, each defining a region for certain types of interaction' (p. 238). In this sense, why the distancing behavior and space zones fluctuate turns out to be an important question to be answered. Knapp 1972 indicates that there are many variables that affect our use of space, which include sex, race, superior-subordinate relations, familiarity, degree of friendship, status, interaction setting, topic of interaction, physical appearance, and desire for approval. However, she fails to take into consideration the broader cultural phenomenon that plays an important role in the interactions particularly between people from different countries. It is interesting to see how this culture motive becomes dominant in the latter definitions of proxemics Hall, an anthropologist who systematically studied it for the first time, made over the years:

(...) the study of how man unconsciously structures microspace- the distance between men in the conduct of daily transactions, the organization of space in his houses and buildings, and ultimately the layout of his towns (1963, p. 1003).

(...) the study of the ways in which man gains knowledge of the content of other men's minds through judgments of behavior patterns associated with varying degrees of [spatial] proximity to them $(1964, \mathrm{p} .41)$.

(...) the interrelated observations and theories of man's use of space as a specialized elaboration of culture (1966, p. 1).

(...) the study of man's transactions as he perceives and uses intimate, personal, social and public space in various settings while following out of awareness dictates of cultural paradigms (1974, p. 2). 
Although culture is emphasized as the focal variable in different proxemic patterns, strange enough, it does not appear in any of the terms associated with the distancing behavior (e.g., interpersonal distance, physical distance, personal space). Because of the nature of this research study in which I explore the similarities and differences between the proxemic patterns of Turkish and American cultures, investigating the issue in terms of Knabb's extremely narrow categories such as gender, degree of friendship and status would not elicit successful results. Therefore, along with Hall's $(1966$; 1974) definitions of proxemics, I have coined the term 'CULTURE-ORIENTED DISTANCE' supposing that culture tells us more than anything about how to organize space in such a way as to control the nature of interaction. My positioning suggests that the physical distance people from different countries maintain has two key components: First, it is unconscious and second, it is culture specific. Curt 1975's description of the physical distance supports this view: 'This is culturally determined a learner behavior carried out day by day out of awareness, and that differs from culture to culture' (p.21).

I am going to use the conceptual framework and categories Hall 1966 came up with. Although he cautions against generalizing them to varied populations, these categories and amounts of distance have generally been accepted as representing North American space norms. Hall indicates that the mixing of various cultureoriented distances in conversation can bring about interesting, but alarming effects. $\mathrm{He}$ found that the comfortable conversation distances for a Latin American or Arab were too close for a North American. Hall points out that when the differing cultures' proxemic behaviors clash 'there is interference during the encounter' (1963:1005). In the case of the Arab and North American encounter he relates that 'Americans were not only aware of the uncomfortable feelings, but the intensity and the intimacy of the encounter with the Arabs was likely to be anxiety provoking' (1963:1005).

Hayduk 1985 has suggested that personal space can best be characterized as a 'momentary preference, strongly dependent on one's preference a moment earlier,' rather than as a relatively static bubble. This is to say that a person might shift distances within categories as well as across them. Felipe and Sommer (1966) have reported research on the effects of spatial intrusion among people with similar cultural backgrounds. In a library setting they found that when there was invasion of subjects' territory, they showed signs of avoidance or flight from the setting. The most clearly defined reactions involved forms of behavior compensation such as withdrawing arms, turning away, or building a barrier with books.

In this section, the focus has been on the discussion of the personal distance in the literature, essentially on Hall's earlier works. Next section will address the research design opted for in this study, including a brief analysis of the setting and participants, and the procedures. 


\section{Research Design}

Because of an interest in comprehending the meaning people have constructed in terms of culture-oriented distance, I used a qualitative design, which I thought would enable me to better understand this social and cultural phenomenon. The basic principle of a qualitative study is that 'meaning is embedded in people's experiences and that this meaning is mediated through the investigator's own perceptions' (Merriam 1998:6). I opted to use phenomenology as type of this qualitative research for two main reasons: First, the study focused on participants' understanding and use of culture-oriented distance as a phenomenon, and secondly, the study used data that were the participants' and, as the investigator, my firsthand experience of this phenomenon.

\section{Setting and Participants}

The study took place in a large Midwestern university in a small town (about $65,000)$ in the United States. The university offers numerous undergraduate, graduate, as well as certification and distance education programs in various fields of study, and has a large international student population from around the world. Because I was interested in studying the differences in culture-oriented physical distancing behavior between the Americans and Turkish people, I used purposeful sampling as the sample selection method, and included only Turkish nationals as participants (Patton 1990:173). My aim was to discover, understand, and gain insight to an issue and selecting a sample from which I could learn the most was essential. Although my original intent was to include at least four students of either gender, I could only locate the two of the four female doctoral students who were EFL teachers with some experience back in Turkey. The rationale behind this selection criterion was my assumption that they, as EFL teachers studying in a U.S. institution for a graduate degree, were more likely to be aware of the cultureoriented distance and the significance of teaching this and other nonverbal behaviors in foreign language classes along with the content knowledge. This selection could also be regarded as convenient sampling because the participants were my colleagues and friends in the same program, who were willing to participate in my study (Merriam 1998:3).

\section{Procedures}

A semi-structured interview protocol (mix of more- and less-structured questions) was developed for this study. The interviews were conducted at different locations determined by the participants' choice (e.g., library, my apartment). The interviews began with broad, open-ended questions (e.g., similarities and differences between Turkey and the U.S., and between the Turkish people and the Americans), and then proceeded to items with culture-oriented distance as a central focus (e.g., differences between the Turkish people and the Americans in the understanding and application of the personal/physical distance) (See Table 1 below). I followed a direct approach (non-disguised) in the interviews so that the purpose of the study was disclosed to the respondents and was obvious given the 
nature of the interview. Each interview took about an hour and was tape-recorded with the participants' consent, and transcribed verbatim. Later, a follow-up question was sent out to the participants via e-mail. Both the interview transcripts and e-mail responses were analyzed and the common themes that emerged were grouped together as certain quotations were chosen to support the claims made in the study.

\section{Table 1: Interview Questions}

1. How long have you been in the United States? How do you like it do far?

2. What do you find to be similar or different between Turkey and the U.S., and between the Turkish people and the Americans?

3. Have you noticed any differences between the Turkish people and the Americans in the understanding and application of the personal/physical distance?

4. Can you describe some situations in which distance issues have come up?

5. Why do you think the distance customs and behaviors vary?

6. Have you lived in or visited countries other than Turkey and the United States? If yes, does the distance change when compared to Turkey and the United States?

Follow up:

As an EFL teacher, what do you think the implication of culture-oriented distance is in English as a foreign language education?

\section{Results}

Both of the participants in this study stated that there were differences between Turkish people and Americans in the understanding and use of personal space. This difference manifested itself in the participants' very first experiences in the United States. Ayla ${ }^{1}$ said:

The very first time I was in the U.S. and I was in the line at the bank, the first time I saw all those silly things that you have to walk in and you have to stop at the certain line, you have to give this distance to the other people, I thought it was so odd, because it is too much distance, it is just too much, it is not a normal distance for me.

In a careful analysis of the participants' views of the phenomenon based on their responses, 'culture' provided enough evidence to be the reason why distance norms and behaviors varied. This has also authenticated the use of the brand new

${ }^{1}$ Ayla is a pseudonym for participant one. 
term, 'culture-oriented distance,' to refer to the phenomenon. In this section, the close connection between culture and distance will be demonstrated through the discussion of results, mainly through certain quotes from the interviews.

The data in this study suggest that the system Hall devised, which I have discussed in the literature review section, applies to virtually all cultures, but that the specific distances within those categories tend to vary across cultures. Turkish personal distance lies within American's intimate distance, just as American's personal distance lies within northern Europeans' intimate distance. Ayla's awareness of the change in the distancing behavior between the Turkish and American cultures supports this view:

In Turkey, it would have been very different for me, the normal distance would be like what half an arm length, like maybe half, like one feet away would not be too offensive, but here even with a close friend, close American friend, a feet apart is too close. That is the distance you can mostly have with a very intimate person, like a girlfriend or a boyfriend, that's acceptable, but normal friend, either sex doesn't matter, it's just too close for them.

As disclosed in my observations I have referred to in the personal excerpt from my memories, and as supported by the participants' responses in this study, when people's standards of distance do not match, they feel uncomfortable, because they think they are either too close or too far-away from one another. Some linguistic expressions from Turkish and English languages would be practical at this point to illustrate this reality as language and culture are interrelated. English expressions, such as 'get your face out of mine' and 'he shook his fist in my face,' show how important body boundaries are for Americans. By contrast, the Turkish expressions 'isirmam' (I don't bite-you) and 'yemem' (I don't eat-you) show the discomfort people from Turkish culture feel when others are too far from them. Ayla, talking about the discomfort she had felt when interacting with people who had kept a distance she had perceived to be atypical, provides a good example of the above fact as well as a strategy she had developed to ease her discomfort:

At first, when I was in U.S., that really bothered me, but now that it's been a little bit over 3 and half years, I'm coping with it, and especially if I know the person is American, I do stay away, I put my distance, but if I know that person is a Turkish person, I'm more comfortable, but more and more sometimes I even get the feeling with a Turkish person that I have to keep a distance because we are in the U.S.

In the exploration of what features in Turkish and American cultures set the scene for different distancing behaviors, several interesting postulations have come 
up. Ayla mentioned the American individualism as opposed to the Turkish collectiveness as a potential reason as to why the two cultures show a discrepancy:

I think, because in the American culture, individuality and praising individuality is so high, and you know, having high self-esteem, stressing individual successes, being one, and only one, and just you know, have a personality of an own, identifying one-self within one-self... Personal space I think is very important at this point.

Serpil $^{2}$, on the other hand, attributed to how the concept of 'respect' might have been constructed differently in the American culture than in the Turkish culture:

They (Americans) might feel that creating this distance might be a kind of respect towards the people that they are dealing with...

She then proceeded to speculate that Turkish culture might have some convictions that put proximity and sociability together. In this sense, keeping a physical distance in the Turkish culture might be regarded as a barrier to a healthy interaction by the members of the society:

The people in Turkey try not to create this distance because they might feel that if they create this distance, they might put some space and they might not feel that they are really connected with the people that they are talking to.

Both of the participants indicated that Turkish students, like many other students who come to the United States for educational purposes, experience some difficulties due to Americans' understanding and use of personal space. However, only Ayla reported problems in relation to the matter whereas Serpil mentioned that she did not have any bad experiences thanks to her awareness of the cultureoriented distance she created after her visit to England. Yet, she was responsive to the fact that the problems Turkish students in the United States come across with respect to culture-oriented distance proves to be one of the common topics in the exchange of ideas between the Turkish acquaintances:

I think, this is one of the issues most of the Turkish people that I have encountered with, most of the Turkish people, have shared with me.

The participants, as EFL learners and teachers, demonstrated recognition of my prior assumption that Turkish students who are always taught linguistic features of

\footnotetext{
${ }^{2}$ Serpil is a pseudonym for participant two.
} 
English and who are not exposed to a valid depiction of American culture in a way find themselves like 'fish out of water' when they first come to the United States although they may have a good command of verbal (linguistic) skills in English. Going back to my personal excerpt, my ability to use the correct linguistic forms was not good enough to communicate successfully with the lady at the O'Hare Airport. A similar experience was reported by Ayla, who was brought up speaking English as her home language and who had a perfect command of the English language:

Like the very first week I was here, I was in Wal-Mart... I saw a baby in a stroller and she was so cute, and I said 'ohh, you are so cute, I wanna bite your toes', and obviously it was a figure of speech, I wasn't really going to bite the toes or anything, but the mommy looked at me and she freaked out, and pulled away the stroller and fled, and so I was really in a shock... If I would have said the same thing in Turkey, the mom would have even picked up the baby and handed it over, even if I am a stranger.

Although not directly related to the distancing behavior, Ayla's experience verifies the importance of socio-linguistic knowledge of what to say, when, where and to whom in addition to the grammaticality and linguistic correctness of our message.

As Turkish culture's interpersonal space patterns are very different from the Americans', it is essential for Turkish learners of English to learn these differences at the same time they learn the language and to adjust their behaviors according to these nonlinguistic norms. If they ignore these differences, it is likely that they will have misunderstandings and failures in their communications with the members of the target language community. In an attempt to offer a practical look at the issue, after discussing the limitations of the study, the final section will be devoted to address the importance of culture-oriented distance and how it can be incorporated into foreign language education with specific reference to Turkish EFL teachers and EFL teaching in Turkey.

\section{Limitations}

There were many limitations to this study. First of all, it included only two participants. Although the participants revealed an adequate amount of data for this study to be completed, using a larger number of participants would strengthen the study. Turkish EFL teachers studying at other U.S. institutions could be included to this study using phone interviews or web-based means of communication such as chat sessions or e-mail messages. This would also be a possible opening to have male participants in such a study in which gender might be a factor in culturerelated issues. Another potential weakness of this study is that there is no triangulation of data as the main source of information comes from the interviews. 
It could be argued that interpersonal distance patterns, once learnt, are maintained largely unconsciously, and that direct questioning in an interview setting is likely to produce insufficient and even inaccurate information. Thus, candid observations of the participants in a range of possible sites (e.g., school, restaurant) could be used as an independent, and an objective measure to obtain more reliable data. Observations would be a rewarding opportunity to see if what the participants perform complies with what they say. Finally, my subjectivity as a researcher was always present in this study as what piloted me to carry out this research was my own experiences and observations as a Turkish EFL teacher in the United States. It was inevitable for me to desire and feel enthusiastic to see that my experiences were akin to my Turkish colleagues'.

\section{So What?}

\section{Implications of This Study in Foreign Language Education}

The knowledge of culture-oriented distance in foreign language education is crucial as it applies to a specific culture or society, and mastering the verbal system of a foreign language does not guarantee effective communication unless the nonverbal system of that language is attained. These two systems cannot be separated and the use of one without the other might lead to misunderstandings and even to suspension of the access to the different sources of communication and information. As Curt 1984 puts it, 'most language teachers are fully aware of the differences that exist between languages, but they may not realize that important cultural differences exist as well' (p.10). She states that teachers often see cultural peculiarities as obstacles to real understanding and effective classroom work although they should try to understand the socialization process of people from other ethnic backgrounds and make use of this in their classes. Considering this view, students' mastery of nonverbal communication can be seen as an aspect of what Hymes 1972 called 'communicative competence,' which mainly articulates that successful communication requires not only grammatically correct, but also socially appropriate utterances. Since language is beyond the words and non-verbal language is part of the mechanism that helps us to 'speak' along with the physical utterances we make, Hymes' concept can be adapted to 'culture-oriented distance'. By doing so, it can be affirmed that culture-oriented distance presents rules of accuracy (e.g., position, distance, space) and rules of appropriateness (e.g., when to use each one and which strategies to use to decipher where to stand and how close to sit, especially when you really do not know).

In addition, comparative and contrastive analysis of cultural factors in L1 and L2 can have a great impact on learners' communication in the target language. By knowing and using the prompts about nonverbal behaviors of the target language community, students can increase their comprehension and expression, hold their listener's attention, and be more successful in the language.

In today's world, where so many different cultures meet in for various reasons such as, but not limited to, education, business and tourism, EFL teaching and 
language teacher education programs should not overlook the differences that exist in terms of culture-oriented distance although it is very complicated to elucidate such non-verbal behaviors. Yet, some might argue that everyone would like to help students access this aspect of communication, but that it is very difficult to identify and describe it in ways that are really authentic. I would advocate that the least we can do as EFL teachers is to emphasize the knowledge of this behavior as well as other aspects of non-verbal language as skills language learners should be aware of, if not master, in order to function adequately in the target language community. However, given that the nonverbal area is very precise, and even the slightest difference can have negative effects, students should be alerted to the fact that these variations in cultural norms are by no means better or worse, but different windows we look at and see the life through. What's more, the study of cultureoriented distance can be regarded as an opportunity for foreign language learners in that it leads to intercultural comparisons and may increase motivation in learning the target language culture as well as create an awareness of the home language culture.

Here, I will provide some possible ways culture-oriented distance can be integrated into EFL classrooms to make the study 'a helpful guide for Turkish EFL teachers' as suggested in the title:

At the outset, the ultimate and only key is 'awareness,' because most Turkish EFL teachers are not conscious of the culture-oriented distance. As revealed in the interview data, Ayşe's unconsciousness of this imperative information almost put her in trouble a few times in her first year in the United States, whereas my other informant, Emine's early perception and alertness helped her avoid any problems pertaining to application of distance. In terms of teaching a foreign language, it is not likely that EFL teachers can transfer the knowledge of a phenomenon they are not even aware of themselves to their students. After becoming aware of cultureoriented distance, the next step for Turkish EFL teachers should be to raise their students' awareness to this issue. This is not to say that EFL learners should be taught to behave in American ways; however, it is their right to be prepared for the differences between American and Turkish cultures with respect to distance in case they might come to contact with the target language community or its members and they might need this survival kit to adapt their spatial relationships to the American style for day-to-day survival, although temporarily. An important point here, as brought up by Ayse in her response to my follow-up question, is that EFL teachers should not make over-generalizations that might cause stereotyping. By knowledge and awareness of culture oriented distance, it is impossible to assume that all individuals in a certain culture think and act in the same way, allowing for the individual differences such as, but not limited to, gender, socio-economic status, familiarity and age. I am not promoting giving the students a list of DOs and DON'Ts as to different categories of distance, rather endorsing the belief that they 
should be made 'wide awake' to the notion of culture-oriented distance that should be seen a skill they should hold on to.

The awareness discussed above can be raised, increased and sustained in many ways in EFL classes. One alternative is through readings. Several books and articles on the topic may well serve the students to learn about culture-oriented distance behavior. After critical reading, students can discuss them with friends and compare the different proxemic norms among the home and target cultures.

Observing people who are native to the American culture, in terms of how the distance is observed by these people, might be a very powerful tool. If students have no access to the native speakers, as is common with EFL context in Turkey, Turkish EFL teachers can promote the use of authentic videos, pictures, and television/movies that should offer a variety of opportunities to look at the topic. Students can be put in different groups or the whole class might work together to compare the culture-oriented distance patterns between the two different cultures. However, as indicated before, prejudices and stereotypes should not be tolerated by the teacher.

Role-plays can help students see the reactions of inappropriate distance behaviors in different cultures. In several scenarios Turkish EFL teachers would create such that one person stands closer than normal to a person they do not know and two friends get farther away while they are interacting, students are likely to create conscious of the ways other people respond. Sharing their ideas and how they felt during the activity would generate a good classroom discussion.

When getting ready for the ideas and activities that incorporate culture-oriented distance, Turkish EFL teachers can make use of their American contacts and/or their Turkish acquaintances (e.g., colleagues, friends, relatives), who have had the knowledge and experience of American culture, as valuable resource of information and advice. There might be well many other potential activities that Turkish EFL teachers would themselves find helpful to add to this list. Getting ideas from students with regard to what type of activities they would like to be included is another option that might inspire and stimulate the students to take the lead for their own learning.

All these suggestions may and should be adapted to the Turkish EFL classrooms to help students avoid cross-cultural misunderstandings. When Turkish EFL teachers realize that their curricular activities do not include enough cultural information related to the native speakers of the target language, they should balance it by adopting or developing texts and using extra materials (pictures, discussion sessions, videos of people interacting, etc.). For instance, beginning with actual photos the students would bring to class has the potential to make a great start for any activity that follows in an EFL classroom. 


\section{Bibliography}

Aiello, J. R. \& Tyra Aiello. 1974. The development of personal space: Proxemic behavior of children 6 through 16. Human Ecology, 2, p. 177-189.

Curt, C. J. N. 1984. Non-verbal communication in Puerto Rico. Cambridge: Evaluation, Dissemination and Assessment Center.

Felipe, N.J. \& Sommer, R. 1966. Invasions of personal space. Social Problems. 14, pp. 214. Hall, E. T. 1959. The silent language. Garden City, New York: Doubleday.

Hall, E. T. 1963. A system for the notation of proxemic behavior. American Anthropologist, 65, p. 1003-1026.

Hall, E. T. 1966. The hidden dimension. Garden City, New York: Doubleday.

Hall, E. T. 1974. Handbook for proxemic research. American Anthropological Association. Washington D.C.: Society for the anthropology of visual communication.

Hall, E. T. 1976. Beyond culture. Garden City, New York: Doubleday.

Hayduk, L. 1985. Personal space: The conceptual and measurement implications of structural equation models. Canadian Journal of Behavioral Science.

Hymes, D. 1972. On communicative competence. In J.B. Pride and J. Holmes (eds.): Sociolinguistics. Harmondsworth: Penguin.

Knapp, M. L. 1972. Nonverbal communication in human interaction. New York: Holt, Rinehart \& Winston.

Little, K. B. 1965. Personal Space. Journal of Experimental Social Psychology, 1, p. 237247.

Mehrabian, A. 1967. Orientation behaviors and nonverbal attitude communication. Journal of Experimental Social Psychology, 17, p. 324-332

Merriam, S. B. 1998. Qualitative research and case study applications in education. San Francisco: Jossey-Bass.

Patton, M. Q. 1996. Qualitative evaluation methods. (2nd ed.) Thousand Oaks, California: Sage.

Poyatas, F. 1983. New perspectives in nonverbal communication. New York: Pergamon Press Inc.

Weitz, S. (Ed.). 1974. Nonverbal communication: Readings with commentary. New York: Oxford University Press. 